원 저

\title{
Clinical Study of Neuron Specific Enolase (NSE) in Small Cell Carcinoma of the Lung
}

\author{
Department of Internal Medicine, College of Medicine, Seoul National University
}

Young Whan Kim, M.D., Joon Woo Kim, M.D., Hyun Ho Kong, M.D. Young Soo Shim, M.D., Keun Youl Kim, M.D. and Yong Choi Han, M.D. $=$ 국문초록 $=$

미분화소세포 폐암에서의 Serum Neuron Specific Enolase(SNSE)의 변동에 관한 연구

$$
\text { 서울대학교 의콰대학 내과학교실 }
$$

김영환 · 김준우 · 공현호·심영수 · 김건열 · 한용철

암표식자 임상연구의 일환으로 신경세포 및 $\mathrm{APUD}$ 계 세포에서 특징적으로 증가한다고 알려진 NS 의 혈청농도를 51 명의 소세포암한자군과 31 명의 대조군에서 방사면역 측정법으로 측정하여 다음과 같 은 결과를 얻었다.

1) 정상대조군 15 명, 비폐암군 6 명, 비소세포암군 10 명에서 축정 한 $\mathrm{SNSE}$ 평균농도는 각각 $9.2 \pm$ $5.4 \mathrm{ng} / \mathrm{ml}, 7.3 \pm 3.2 \mathrm{ng} / \mathrm{ml}, 13.9 \pm 5.8 \mathrm{ng} / \mathrm{ml}$ 였다.

2) 소세포암환자군에서의 SNSE 평균농도는 $43.0 \pm 30.4 \mathrm{ng} / \mathrm{ml}$ 로서 대조군에 비하여 유의하게 증 가되었다.

3) 소세포암 환자군에서의 Limited Disease 의 평군농도는 $27.4 \pm 15.2 \mathrm{ng} / \mathrm{ml}$, Extended Disease 에서는 $49.8 \pm 32.8 \mathrm{ng} / \mathrm{ml}$ 로 소세고ㅇㅏㅏㅁㅇㅢ 진행정도에 따라 SNSE 의 농도가 증가함을 보여주었다.

4) 화학요법치료후 부분간해 도는 완전관해가 온 환자의 SNSE 평균농도는 $8.0 \pm 6.1 \mathrm{ng} / \mathrm{ml}$ 로 정 상치와 통계학적으로 유의한 차이가 없었으며 치료에도 불구하고 암이 진행 된 흰자의 SNSE 평균농 도 $97.6 \pm 39.7 \mathrm{ng} / \mathrm{ml}$ 는 치료전의 환자군에 비하여 증가되어 있었다.

5) 이상의 결과로 SNSE 측정은 소세포암의 진단 및 진행정도의 판정뿐만 아니라 치료에 대한 반 응을 판정하는 암표식자로 유용하게 사용릴 수 있음을 알 수 있었다.

\section{Introduction}

Histologic classification of lung cancer is becoming more important in clinical practice due to wide therapeutic application of cancer chemotherapy and radiation therapy. The classification

* This study was presented at the 37 th annual meeting of the Korean Association of Internal Medicine

* This study was supported in part by $1984 \mathrm{Re}$ search Grant of Seoul National University Hospital which was adopted by the W.H.O. Committee(19 80) include(1) Squamous-cell carcinoma(Epidermoid carcinoma), (2) Small-cell carcinoma, (3) Adenocarcinoma, (4) Large cell carcinoma, (5) Adenosquamouscarcinoma, and this classification was designed by the observed tumor cell appearances as seen by light microscopy and known to make no attempt to base the histogenetic classification.

Among the above variety of histologic types of lung cancer, small-cell carcinoma comprises about $20-25 \%$ of total lung cancer and has been known 
Table 1. Patient Categories \& its Distribution

\begin{tabular}{|c|c|}
\hline Patient categories & Subclassification \\
\hline SCLC (51) & $\begin{array}{l}\text { Limited disease (23) } \\
\text { Entended disease }(28)\end{array}$ \\
\hline NSCLC (10) & $\begin{array}{l}\text { Squamous cell ca (7) } \\
\text { Adenocarcinoma (3) }\end{array}$ \\
\hline Other cancer (6) & $\begin{array}{l}\text { Gastrointestinal } \\
\text { tract tumor }(3) \\
\text { Lymphoma }(2) \\
\text { Meningioma (1) }\end{array}$ \\
\hline Normal subjects (15) & \\
\hline Total & 82 \\
\hline
\end{tabular}

as the most rapidly progressing variety of lung cancer and also being the one of the most sensitive cancer to anti-cancer chemotherapy ${ }^{1 \sim 2}$. Another unique aspect of this small-cell lung carcinoma is its histogeneic relation with APUD (Amine Precursor Uptake and Decarboxylation) and its capability to produce paraneoplastic syndrome by APUD enzymes, hormones and polypeptides substances ${ }^{3 \sim 4}$ ).

These kinds of biologic substances which derived from tumor has been studied extensively as a possible tumor marker ${ }^{5}$ and many attempts have been made to correlate with clinical stage, diagnosis, therapeutic response and for the detection of recurrence of various carcinomatous diseases ${ }^{6}$.

Neuron Specific Enolase is one another kind of neuron specific protein and has been known to be increased among the patients with non-functioning islet cell tumor ${ }^{7)}$, small-cell carcinoma ${ }^{8)}$ and neuroblastoma ${ }^{9}$.

The following study attempted to evaluate the diagnostic and prognostic significance of serum
Neuron specific Enolase(NSE) for the small-cell carcinoma of the lung among the Korean population.

\section{Materials and methods}

The group under study includes 51 patients with small-cell lung cancer and 31 control subjects including 15 normal, 6 other types of cancer and 10 non-small cell cancer of the lung(Table 1). All patients under study were histologically proven cancer patients by bronchofiberscopic biopsy, percutaneous needle aspiration biopsy, pleural biopsy, lymph node biopsy or cytologic examination of sputum and pleural fluid ${ }^{10}$.

Clinical staging of small-cell lung carcinoma was made into simple two stage system of Limited disease(LD) and Extended disease(ED) ${ }^{11}$. LD category was 23 subjects and ED category was 28 patients.

Treatment modality comprises chemotherapy of VP-16, Ifosfamide and Cisplatin/Cyclophosphamide, Adriamycin and Vincristin alternative treatment and radiation therapy for $L D$ and che motherapy only for ED.

The criteria of treatment response was determined into 4 catgories as complete remission(CR), partial remission(PR), stationary disease(SD) and progressive disease(PD) (Table 2).

The assay of serum Neuron Specific Enolase was made by EIKEN radioimmunoassay kit, supplied by EIKEN Immunochemical Laboratory. The principle of assay is based on the immunologic reaction using $\mathrm{I}^{125}$-labeled NSE tracer and NSE standard curve. All serum samples were kept frozen at $-20^{\circ} \mathrm{C}$ until assay procedure undertaken and

Table 2. Criteria of Response

\begin{tabular}{ll}
\hline \hline Complete remission (CR) & $\begin{array}{l}\text { Disappearance of all clinical evidence of disease } \\
\text { Partial remission (PR) }\end{array}$ \\
Reduction by at least $50 \%$ in the sum of all measurable disease \\
Reduction by less than $50 \%$ in the sum of all measurable disease \\
or no change
\end{tabular}


Table 3. Comparison of SNSE Titers in Various Categories of Patients

\begin{tabular}{lc}
\hline Patient categories & Mean $\pm \mathrm{SD}(\mathrm{ng} / \mathrm{ml})$ \\
\hline SCLC & $43.0 \pm 30.4$ \\
Limited disease & $27.4 \pm 15.2$ \\
Extended disease & $49.8 \pm 32.8^{* * * *}$ \\
NSCLC & $13.9 \pm 6.7^{* * *}$ \\
Other cancer & $7.3 \pm 3.2^{* *}$ \\
Normal subjects & $9.2 \pm 5.4^{*}$ \\
\hline
\end{tabular}

SCLC:Small cell lung cancer

NSCLC:Non-small cell lung cancer

* Comparison between SCLC and Normal Subje$\operatorname{cts}(\mathrm{P}<0.005)$

** Comparison between SCLC and other Cancer $(\mathrm{P}<0.01)$

*** Comparison between SCLC and NSCLC $(\mathrm{p}<$ 0.005)

**** Comparison between subgroups of SCLC $(\mathrm{p}<0.05)$

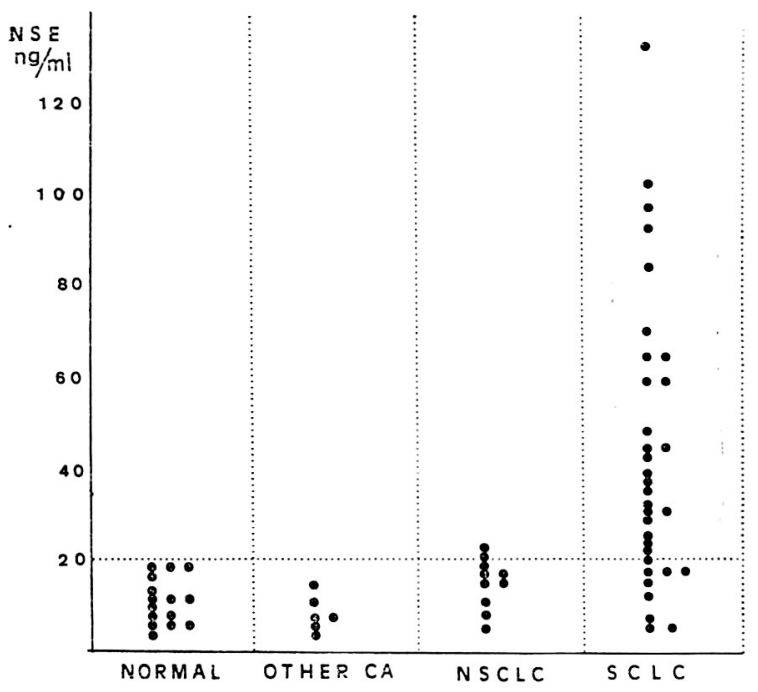

Fig. 1. SNSE titers in various categories of patients. (SCLC:Small cell lung cancer NSCLC:Non-small cell lung cancer)

were assayed duplicates.

The statistical analysis was done using Student's t-test.

\section{Results}

1) Serum Neuron Specific Enolase(SNSE) con-

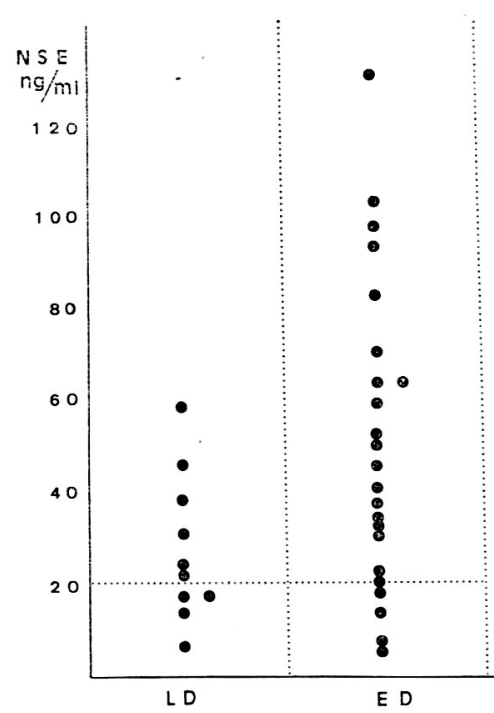

Fig. 2. SNSE titers in subgroups of small cell Lung cancer.(LD: Limited disease, ED: Extended disease)

were assayed centration of the normal control $\operatorname{subjects}(\mathrm{N}=15)$ was $\quad 3.0 \sim 19.0 \mathrm{ng} / \mathrm{ml}(9.2 \pm 5.4 \mathrm{ng} /$

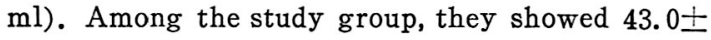
$30.4 \mathrm{ng} / \mathrm{ml}$ in small-cell carcinoma of the lung $(\mathrm{N}$ $=51), 13.9 \pm 6.7 \mathrm{ng} / \mathrm{ml}$ in non-small cell carcinoma of the lung $(\mathrm{N}=10)$ and $7.3 \pm 3.2 \mathrm{ng} / \mathrm{ml}$ in other nonpulmonary cancer $(\mathrm{N}=6)$, respectively (Table 3, Fig. 1). The small-cell lung carcinoma group showed significant higher value compared with other group of normal control, non-small cell lung cancer and other cancer group.

2) In comparison between subgroups of smallcell lung carcinoma, limited disease showed 27.4 $\pm 15.2 \mathrm{ng} / \mathrm{ml}$ and $49.8 \pm 32.8 \mathrm{ng} / \mathrm{ml}$ in extended disease which is also significantly higher in extended disease group(Table 3, Fig. 2).

3) SNSE was also measured at pre and postchemotherapy of small-cell lung carcinoma for the comparison between the disease progression. Eighteen subjects who have clinical remission (partial or complete) showed $8.0 \pm 6.1 \mathrm{ng} / \mathrm{ml}$ and 5 subjects who have disease progression in spite of chemotherapy showed $97.6 \pm 39.7 \mathrm{ng} / \mathrm{ml}$ which is significantly higher than the pre-treatment values (Table 4, Fig. 3,4). 
Table 4. Comparison of SNSE Titers Before and After Treatment of Small Cell Lung Cancer

\begin{tabular}{lc}
\hline \hline Patient categories & Mean $\pm \mathrm{SD}(\mathrm{ng} / \mathrm{ml})$ \\
\hline Before treatment & $43.0 \pm 30.4$ \\
After treatment & \\
Remission & $8.0 \pm 6.1^{*}$ \\
Progression & $97.6 \pm 39.7^{*}$
\end{tabular}

* Comparison between pretreatment and posttreatment $\operatorname{group}(\mathrm{p}<0.005)$

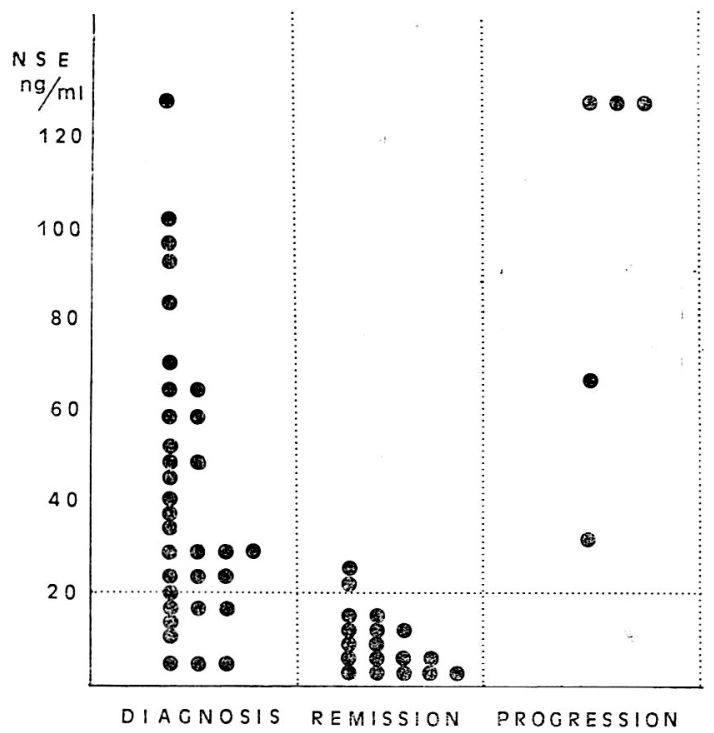

Fig. 3. SNSE titers in various states of small cell lung cancer.

\section{Discussion}

It has been known that malignant cells produce hormones, proteins, enzymes and many kinds of cellular metabolic products. Some of them are used as tumor marker for early detection, diagnosis and staging of malignancy and evaluation of treatment $t^{12)}$. Also there have been trials to use them tagged to anticancer agents as treatment vehicles.

But, there are requirements for these materials to be used as tumor marker. First, they should be able to differentiate malignancy from normal or benign conditions. Second, they should have

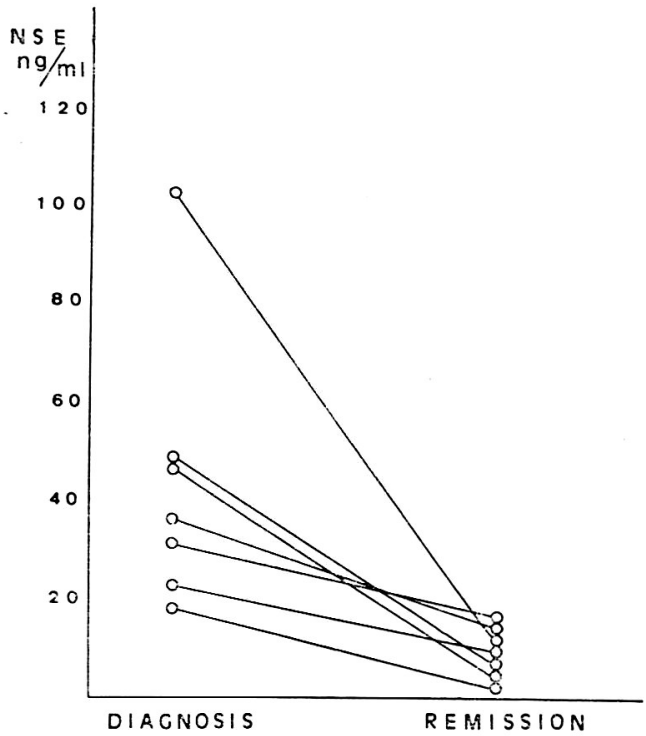

Fig. 4. Comparison of SNSE titers at the time of diagnosis and during remission.

high sensitivity and specificity. Third, they should have organ specificity. Also, to be used clinically, they should be used for differential diagnosis from other diseases and for follow-up of treatment.

But, unfortunately, no material has fulfilled these requirements and some materials which fulfilled some of these requirements have been used clinically. Since Goldberger and Freedman found CEA(Carcinoembryonic antigen) in embryonal cells and colon cancer in 1965, CEA has been used as a convenient and sensitive method to predict the recurrence of cancer after colon cancer surgery ${ }^{13)}$. $\alpha$-feto protein in primary liver cancer, HCG (Human Chorionic Gonadotropin) in trophoblastic tumor and germ cell tumor, and acid phosphatase isoenzyme in prostate cancer are examples used in clinical medicine.

In the case of lung cancer, many tumor markers were tried, but could not be used widely because of their low specificity ${ }^{14)}$. On the other hand, since NSE was found to increase in neuroendocrine and APUD tumors ${ }^{15}$ ) there have been many researches on the utility of NSE in small-cell lung cancer which is known to be originated from APUD system ${ }^{8,16)}$. 
Neuron Specific Enolase is acid protein which Moore et al separated in bovine brain cells using DEAE cellulose chromatography and electrophoresis in $1965^{17}$. Bennet et al found $\alpha$-antigen which was present in rat brain cells specifically and reported that it was different from material found by Moore ${ }^{18)}$. But Marangos et al confirmed that these two materials were identical ${ }^{19}$. Marangos also found that these material was present only in neuron but not in glial cells. So this material was called Neuron Specific Protein ${ }^{20,21)}$. Soon it was found to have enolase activity.

In 1980 Hullin et al found NSE in human brain by radioimmunoassay and subsequently in almost every tissue of human body ${ }^{22}$. But concentration of NSE in other tissues were less than $3 \%$ of the brain and was thought to be the result of nerve supply. But, because NSE was found in RBC's which have no innervation, the explanation was not verified ${ }^{23)}$.

In 1978 Schmachel et al found NSE in APUD cells and subsequently Prinz et al noticed increase of NSE in non-functioning islet cell tumor $\left.{ }^{24} 26\right)$. Because small-cell lung cancer is from APUD system, application of NSE in this disease was tried by Carney et al. He reported that NSE could be used as a tumor marker in small-cell lung cancer and similar results were reported by Akoun ${ }^{27}$ ) and Essher ${ }^{2 \varepsilon}$.

The authors measured serum NSE concentration in normal subjects, small-cell lung cancer patients, non-small cell lung cancer patients and other cancer patients. Mean serum concentration in small cell lung cancer patients was significantly raised compared with other groups. And ED of smallcell lung cancer patients group the mean concentration of NSE was significantly higher than that of LD. This means that serum NSE inereases according to the degree of tumor progress and the results were similar to those of Carney, Ariyoshi, Akoun and Essher ${ }^{20}$.

We tentatively took upper limit of normal value as $20 \mathrm{ng} / \mathrm{ml}$ which is mean plus $2 \mathrm{X}$ standard deviation. According to this value the sensitivity was $72.7 \%$ and the specificity was $93.6 \%$. In $\mathrm{LD}$ 6 patients out of $10(60 \%)$ had serum NSE value above $20 \mathrm{ng} / \mathrm{ml}$ and in ED 18 patients out of 23 (78.3\%) had value above $20 \mathrm{ng} / \mathrm{ml}$. In normal subjects ard other cancer group there was none who had NSE concentration above $20 \mathrm{ng} / \mathrm{ml}$ and in non-small cell lung cancer group only 2(20\%) had value above $20 \mathrm{ng} / \mathrm{ml}$. And in small cell lung cancer patients, the patients whose value were above $60 \mathrm{ng} / \mathrm{ml}$ were all ED patients. According to this result we could find that NSE could be used for diagnosis and staging of small cell lung cancer.

The mean serum NSE concentration of the patients who had partial or complete remission after chemotherapy or radiation therapy decreased to the value similar to the normal subjects. Cn the other hand, the mean serum NSE concentration of the ratients whose disease progressed despite of treatment was remarkably raised. So we concluded that NSE is a useful tumor marker for monitoring the clinical course during treatment of small-cell ling cancer.

\section{REFERENCES}

1) Cohen MH, Mathews MJ: Small cell bronchcgenic carcinoma; A distinct clinicopathologic entity. Semin Oncol 5:234, 1978

2) Greco FA, Oldham RK: Current concepts in cancer; Small cell lung cancer. N Eng J Med 301:155, 1979 .

3) Baylin SB, Abeloff MD, Wieman KC, Tomford JW, Ettinger DS: Elevated histaminase activity in small cell carcinoma of the ling. $N$ Eng $J$ Med 2£3:(25) :1286-1290

4) Eagan RT, Maurer LH, Forcier RJ, Tulloh $\mathrm{M}$ : Small cell carcinoma of the lung; Stagirg, paraneoplastic syndromes, treatment and survival. Cancer 33:527, 1974

5) Aroney R.S, Dermody WC, Aldenderfer P, Parsons $\mathrm{P}$, McNitt K, Marangos PJ, Whitacre MY, Ruddon RW, Wiernik PH, Aisner J: Multiple sequential biomarkers in monitoring patients with carcinoma of the lung. Cancer 
Treatment Reports 68(6):859-668, 1984

6) Marangos PJ, Neurath CZ, York C: Immunologic studies of a nerve specific protein. Arch Biochem Biophys 170:289-293, 1975

7) Prinz R, Marangos PJ: Serum NSE in "nonfunctioning" islet cell carcinoma. Lancet $\mathrm{Feb}$ 6:1(8267):340, 1982

8) Carney DN, Marangos PJ, Ihde DC, Bunn PA, Cohen MH, Minna JD: Serum NSE; A marker for disease extent and response to therapy of SCLC. Lancet Mar 13:1(8272): 583-585, 1982

9) Tsokos M, Linnoila RI, Chandra RS, Triche TJ: Neuron-specific enolase in the diagnosis of neuroblastoma and other small, round-cell tumors in children. Human Path 15(6):575584, 1984

10) Hande KR, Des Prez RM: Current perspectives in small cell lung cancer. Chest 85(5):669675,1984

11) Mountain CF, Carr DT, Anderson WA: A system for the clinical staging of lung cancer. Am J Roentgenol Radium Ther Nucl Med 120: 130, 1974

12) Mclntire KR: Tumor markers; How useful are they? Hospital Practice 12:55-68, 1984

13) Go VLW, Zamcheck N: The role of tumor markers in the management of colorectal cancer. Cancer 50(11):2618-2623, 1982

14) Vincent RG: Biologic markers in lung cancer. Seminars in respiratory medicine 3(3):184-193, 1982

15) Schmechel D, Marangos P: NSE is a molecular marker for peripheral and central neuroendocrine cells. Nature 276:834-836, 1978

16) Ariyoshi $Y$, Kato $K$, Ishiguro $Y$, Ota $K$, Sato $T$, Suchi $T$ : Elevation of serum NSE as a tumor marker for carcinoma of the lung. Gann 74:219-225, 1983

17) Moore BW, McGregor D: Chromatographic and electrophoretic fractionation of soluble proteins of brain and liver. J Biol Chem 240 (4) :1647-1653, 1965

18) Bennet GS, Edelman GH: Isolation of an acidic protein from rat brain. J Biol Chem 243(23):
6234-6241, 1968

19) Marangos PJ, Neurath CZ, Luk DCM, York $\mathrm{C}$ : Isolation and characterization of the nervous system-specific protein $14-\hat{\mathrm{s}}-2$ from rat brain. J Biol Chem 250(5):1884-1891, 1975

20) Marangos PJ, Neurath CZ, York C: Determination and characterization of neuron specific protein associated enolase activity. Biochem Biophys Res Com 68(4)1309-1316, 1976

21) Marangos PJ, Neurath CZ, York C, Bondy SC: Axoplasmic transport of a brain specific soluble proteins. Biochim Biophys Acta 392:75-81, 1975

22) Hullin DA, Brown $K$, Kynoch $P$, Smith $C$, Thomson RJ: Purification, radioimmunoassay and distribution of human brain 14-3-2 protein (Nervous-system specific enolase) in human tissues. Biochim Biophys Acta 628:98-108, 1980

23) Thomson RJ, Day IN: Measuring serum neuronspecific enolase. Lancet May 15:1(8281):1126, 1982

24) Prinz RA, Bermes EW, Kimmel JR, Marangos $\mathrm{PJ}$ : Serum markers for pancreatic islet cell and intestinal carcinoid tumors; A comparison of neuron-specific enolase, $\beta$-human chorionic gonadotropin and pancreatic polypeptide. Surgery 94 : (6) :1019-1023, 1983

25) Prinz RA, Marangos PJ: Use of NSE as a serum marker for neuroendocrine neoplasm. Surgery 92(5):887-889, 1982

26) Prinz RA, Marangos PJ: Serum neuron-specific enolase; A marker for nonfunctioning pancreatic islet cell carcinoma. Am J Surg 145(1) :77-81, 1983

27) Akoun GM, Scarna HM, Milleron BJ, Benichou MP, Herman DP: Serum neuron-specific enolase; A marker for disease extent and response to therapy for small cell lung cancer. Chest 87 (1) :39-43, 1985

28) Esscher T, Steinholtz L, Bergh J, Nou E, Nilsson K, Pahlman S: Neuron specific enolase; A useful diagnostic serum marker for small cell carcinoma of the lung. Thorax 40: 85-90, 1985

29) Marangos PJ, Carney DN, Polak JM, Pearse AJ: Neuron specific enolase and small cell cancer of the lung. The endocrine lung in health and disease 1st ed. Saunders Company Phil. p 509-515, 1984 